\title{
Corporate Governance and External Mechanism on Organizational Performance. (Evidence From Quoted Manufacturing Firms in Nigeria)
}

\author{
Olaifa, Olubunmi Ikeolape PhD \\ Department of Management and Accounting, \\ Faculty of Management Sciences \\ Ladoke Akintola University of Technology, P. M.B. 4000, Ogbomoso, Nigeria \\ Arulogun, Olaleye \\ Department of Management and Accounting, \\ Faculty of Management Sciences \\ Ladoke Akintola University of Technology, P. M.B. 4000, Ogbomoso, Nigeria
}

\begin{abstract}
Corporate governance is regarded as the key foundation for effective organizational performance and for organizations to be more productive, governed and controlled. The level of collapse of institutions and failure of firms across the world has also emphasized the need to study the ways by which organizations are governed and controlled. Despite these advancements, organizations are still faced with challenges such as the separation of ownership and control. Formal legal and regulatory obligations are part of the external incentive structure designed to ensure that competing companies abide by common standards of fairness, transparency, accountability, and responsibility to protect shareholders, consumers, workers, the environment, and even competitors from abusive practices. The general objective of the study was to examine the impact of corporate governance and external mechanism on organizational performance. The specific objectives of the study were to examine if separation of ownership and control affects the performance of listed manufacturing company in Nigeria and to determine the significant effect of laws/regulators on the performance of listed manufacturing company in Nigeria. The population of this study comprised all quoted manufacturing companies in the Nigerian Stock Exchange as at 2019. The study adopted secondary data. The secondary data was extracted from the Annual Reports of the sampled companies for a period of ten (10) years (2010-2019). The descriptive method which includes frequency tables, percentage, mean and standard deviation was used in describing and explaining information obtained from audited annual report of quoted manufacturing company while the quantitative method includes regression analysis. The main findings from the empirical analysis are that there is a significant relationship and effect between separation of ownership and control on the performance of listed manufacturing company given a P-value of 0.0005 , RSquared of 0.9712 , adjusted $\mathrm{R}^{2}$ of 0.9481 and F-value of 42.14. Also, the analysis revealed that laws/regulators on the performance of listed manufacturing company in Nigeria (LR) is significant given a P-Value of 0.0017 and FValue of $51.10, \mathrm{R}^{2}$ of 0.8031 and adjusted $\mathrm{R}^{2}$ of 0.6456 . The empirical results of this study revealed that external mechanism of corporate governance has impact on the performance of manufacturing firms in Nigeria. Based on the findings and conclusion, the study therefore recommended that regulatory bodies should ensure that the Manufacturing Companies comply with the statutory rules and regulations of corporate governance act.
\end{abstract}

Keywords: Corporate governance, external mechanism, organizations and performance

DOI: $10.7176 / \mathrm{EJBM} / 12-24-02$

Publication date:August $31^{\text {st }} 2020$

\section{Introduction to the Study}

Corporate governance is regarded as the key foundation for effective organizational performance and for organizations to be more productive, governed and controlled. The level of collapse of institutions and failure of firms across the world has also emphasized the need to study the ways by which organizations are governed and controlled. Corporate governance is a system by which business corporations are directed and controlled (Babatunde and Olaniran, 2009). The corporate governance structure specifies the distribution of rights and responsibilities among different participants in the corporation, such as the board, managers, shareholders and other stakeholders, and spells out the rules and procedures for making decisions on corporate affairs. By doing this, it provides the structure through which the company objectives are set, and the means of attaining those objectives and monitoring performance." It has been reported that the survival of firms is associated with the type of corporate governance and management followed in the organization (Shleifer, 2016).

Corporate Governance also includes the relationships among the many stakeholders involved and the goals for which the corporation is governed. In contemporary business corporations, the main external stakeholder groups are shareholders, debt holders, trade creditors, suppliers, customer and communities affected by the 
corporation's activities (Hermalin, 2014). Informal stakeholders are the board of directors, executives and other employees. Corporate Governance guarantees that an enterprise is directed and controlled in a responsible, professional, and transparent manner with the purpose of safeguarding its long-term success which is intended to increase the confidence of shareholders and capital market investors (Oyejide, and Soyibo, 2016).

Corporate governance comprises of two mechanisms, internal and external corporate governance. Internal corporate governance, giving priority to shareholder's interest, operated on the board of directors to monitor top management (Metrick, 2012). On the other hand, external corporate governance monitors and controls manager's behaviours by means of external regulations and force, in which many parties, such as suppliers, debtors (stakeholders), accountants, lawyers, and providers of credit and investment bank. In the past, so many corporate organizations have been caught of getting involved in unethical practices, for example the discovery of financial scam by the Central Bank of Nigeria after the consolidation exercise, involving seven top bank executives in Nigeria, which puts the credibility of their corporate image under suspicion, which further shocking investors' confidence (Organization for Economic Corporation and Development, 2014).

Apparently, corporate governance mechanism has been considered as fundamental in determining the performance of an organizational. Based in this fact, the study tends to examine the impact of corporate governance and external mechanism on organizational performance in Nigeria.

\section{Statement of the problem}

The emergence of corporate scandals, stronger demand for accountability, transparency and performance in the global arena has placed corporate governance at the center of strategic management debate (Miyajima Hideaki, Kenji Haramura, and Yoshinari Enami., 2015). Despite these advancements, organizations are still faced with challenges such as the separation of ownership and control (Metrick and Ishii, 2012). This separation leads to emergence of governance issues where the three main corporation's stakeholders interplay. Since agency costs are relatively high for organizations with dispersed ownership of shares, shareholders demand greater information disclosure for monitoring purposes. The situation calls for strong corporate governance as transparency is reduced by ownership concentration.

Formal legal and regulatory obligations are part of the external incentive structure designed to ensure that competing companies abide by common standards of fairness, transparency, accountability, and responsibility to protect shareholders, consumers, workers, the environment, and even competitors from abusive practices. A good legal and regulatory framework efficiently addresses the entry, operations, and exists of firms. The day-to day performance of a company's shares on a stock exchange is a transparent reminder to managers and Owners of the company's perceived viability and value. This assessment permits shareholders to assess management performance and gives managers an incentive to minimize the costs of equity, since failure to do so will make them vulnerable to takeover. The overall impact of the laws or regulations binding the corporate governance framework should advocate for the rule of law and transparency (Jensen, 2001). This deals with the possibility of corporate fraud and issues to do with ethics.

It is based on this problem that the research seeks to study the impact of corporate governance and external mechanism on organizational performance in Nigeria; using listed manufacturing company in Nigeria as a case study.

\section{Research Objectives}

The general objective of the study is to examine the impact of corporate governance and external mechanism on organizational performance. The specific objectives of the study are;

i. to examine if separation of ownership and control affects the performance of listed manufacturing company in Nigeria.

ii. to determine the significance effect of laws/regulators on the performance of listed manufacturing company in Nigeria.

\section{Literature review}

\subsection{Concept of Corporate Governance}

Corporate governance as a concept has varied definitions which ultimately describes how companies are managed and controlled. Babatunde and Olaniran (2009) Opined that corporate governance apparatus is twofold, internal and external. Internal Corporate governance embodies giving precedence to owner's concerns and ensuring that the board checks on top management serving as a link between management and the owners. External corporate governance examines and controls executive actions by means of external policies concerning other stakeholders. Cadbury report (2012) emphasized that corporate governance deals with shareholders wealth maximization and efficient utilization of firms assets.

Corporate governance characteristics are statutory requirements that protects outside shareholders from expropriation by administrators, insiders or managing shareholders. Where such mechanisms are in nonexistence, 
difficulties of monitoring are suffered by outside investors while administrators or managers may misuse organizational assets at the expense of small shareholders and this will impact on the long run performance of firms (Ammar et al, 2013) Corporate governance is basically concerned with building trust, ensuring accountability and transparency as well as maintaining an effective channel of information disclosure which helps to bridge the gap between information available to directors and the information available to stakeholders thereby helping to resolve the agency problem and foster good performance of firms (Magbagbeola, 2015).

\subsection{External Mechanism of Corporate Governance}

\section{i. Laws/Regulations}

Firms have to abide by the regulatory and legislative requirements which are basically drawn from the host country's specific circumstances, history and tradition. The regulatory and legislative framework differs from country to country. The overall corporate performance is greatly influenced by regulatory and legal environment within which the firm operates. The policy makers in turn should put in place a framework that is flexible enough to meet the needs of the corporations operating in widely different circumstances. The overall impact of the laws or regulations binding the corporate governance framework should advocate for the rule of law and transparency (Jensen, 2011). This deals with the possibility of corporate fraud and issues to do with ethics. Corporate governance practices and requirements are bound by an array of legal aspects such as securities regulation, company law, auditing and accounting standards, insolvency law, contract law, labour and tax laws. Human rights and environmental laws are also very important as these affect the overall treatment of the environment and labour. Labour should be fairly remunerated; health and safety issues should be of paramount importance. Social responsibility by the firms should be viewed and implemented as a developmental gesture of appreciation to the community in which the firm operates. Board of directors and management should prioritize this crucial obligation in order to earn respect and support from host communities and host country at large (Hermalin, 2014).

\section{ii. Ownership Concentration}

In financial and general management positive agency theory put forward that a wider spreading of share ownership is related with greater transparency. Jensen, (2011) contends that the separation of control and ownership creates agency costs as a result of differing and conflicting interests between owners and management. Since agency costs are relatively high for organizations with dispersed ownership of shares, shareholders demand greater information disclosure for monitoring purposes. The situation calls for strong corporate governance as transparency is reduced by ownership concentration.

\section{iii. Foreign Ownership}

Strategic management scholars argue that when an organization goes international the uncertainty of a company's business operations and complexity increases. Stakeholders are then likely to place greater pressure on the company to ensure it implements effective monitoring mechanisms. According to Gugler (2012) multinational organisations' performance, behavior and consequences of their operations are closely monitored by international government agencies and political pressure groups. As a result, foreign investors are required to comply fully with all regulatory and statutory requirements of the host countries for their international subsidiaries. International subsidiaries will probably have more complicated financial reporting systems that facilitate greater disclosure in their end of year reports compared to local companies. There is indication of positive correlation between foreign ownership and corporate disclosure as established in recent studies by (Gompers et al., 2013).

\subsection{Theoretical Framework}

\section{i. Agency Theory}

This theory propounded by Jensen and Meckling (1976) is based on the premise that when ownership of an organization is separated from control, managers acting as agents on behalf of the owners or principal are prone to pursuing their own interest to the detriment of the owners. It further emphasized that managers have interest which does not align with maximizing returns to shareholders thus creating agency problem between shareholders (principal) and directors (agents). The principal has to bear some agency cost in order to monitor the activities of the agent to ensure efficiency.

\section{ii. Stakeholders' theory}

According to Bessong and Tapang (2012), the concept of agency theory is narrow. This is because they identify shareholders as the only interest group of a corporate entity necessitating further exploration. By expanding the spectrum of interested parties, Wolfensohn, (2009) argue that, the stakeholder theory stipulates that, a corporate entity invariably seeks to provide a balance between the interests of its diverse stakeholder in order to ensure that each interest's constituency receives some degree of satisfaction. In separate contribution, According to Shleifer (2016), stakeholder theory appears better in explaining the role of corporate governance than the agency theory by highlighting the various constituent; employees, banks, governance, relevant stakeholders.

Freeman (2004) provide a comprehensive review of the stakeholders' theory of corporate governance which points out the presence of many parties with competing interests in the operations of the firm. They also emphasize 
the role of non-market mechanisms such as the size of the board, committee structure as important to firm performance (Shleifer and Vishny, 2016). Stakeholder theory has become more prominent because many researchers have recognized that the activities of a corporate entity impact on the external environment requiring accountability of the organization to a wider audience than simply its shareholders (i.e. stakeholders). For instance, Savage, Nix, Metrick and Ishii, (2012) proposed that companies are no longer the instrument of shareholder alone but exist within society and therefore, have responsibilities to that society. One must however point out that large recognition of this fact has rather been a recent phenomenon. Indeed, it has been realized that economic value is created by people who voluntarily come together and corporate to improve everyone's position (Freeman, 2004).

\subsection{Empirical Review}

Several empirical studies have investigated corporate governance and performance of firms (Adebayo et al 2014; and Ammar et al;(2013) ). But Gadi, Emesuanwu and Shammah, (2015) extended their study by examining corporate governance and financial performance of Micro Finance Banks in North Central Nigeria. Their study sampled 23 micro finance banks that board composition and composition of board committees have significant relationship with banks financial performance. Similarly, Adenikinju (2017) studied 30 manufacturing companies quoted on the Nigerian Stock Exchange Market between 2003 and 2007. The findings portray a significant but weak link between board size and Manufacturing firms in Nigeria. In addition, Ogbechie and Koufopoulos (2010) investigated the correlation between corporate governance and board practices in the Nigerian banking industry. The result discovered that a standard board size comprising of all board committees is ideal for any organizational set up. Similarly, Adebayo, Ibrahim, Yusuf and Omah (2014) studied corporate governance and performance of organizations. The study adopted quantitative methodological framework. The finding showed that board size, board skills, management skills and size of audit committee are positively associated with performance in organizations.

According to Adenikinju and Ayorinde (2017), who examined the link between corporate attributes of board size and market value of firms, using a sample of six companies, between 2004-2012, results from the study indicate a negative correlation between board size and the market value of equity. In addition, Ammar, Asif and Ammar (2013) examined Corporate governance and performance from the Pakistan context, the study utilized data from the website of Karachi stock exchange and financial statements of sampled listed companies for the period of five years 2007-2011. The findings revealed a positive association between board size and firm performance. Yermack (1996) also investigated the relation between board size and firm performance. 452 sampled industrial firms for the period 1984-1991 were used for the study, concluding that the smaller the board sizes, the better the performance. Monks and Minow (1995) argued that large boardroom tends to be slow in decision making and hence can be an obstacle to change. Previous researchers investigated corporate governance and Firm performance but this paper stands to differ by examining corporate governance and external mechanism on organizational performance of manufacturing companies proxied by determinant of external mechanism of corporate governance in an organization which include; separation of ownership, ownership structure laws and regulation e.t.c

\section{Methodology}

The population of this study comprised all quoted manufacturing companies in the Nigerian Stock Exchange as at 2019, and the number of such companies is sixty-three (63) (NSE Bulletin, 2019). Stratified Sampling was used for this study. Stratified sampling is a method of sampling from a population which can be partitioned into subpopulations. This technique was used to select a company each from each sub sector of the manufacturing industry, which therefore makes four companies as sample size of the study. These companies are Nestle Nig. PLC, Lafarge Africa Plc., Presco Plc and A.G. Leventis Nig Plc. Nestle Nigeria Plc, has been in existence for a long period of time and they operate in consumer goods industry, Lafarge Africa Plc is a manufacturing firm within the industrial goods/ building materials subsectors, Presco is in agriculture industrial goods subsector while A.G. Leventis Nig Plc is a conglomerates majorly involved in automobiles. The study adopted secondary data. The secondary data will be extracted from the Annual Reports of the sampled companies for a period of ten (10) years (2010-2019). Considering the nature and purpose of the research work, inferential method was used for the analysis of the various data collected. The quantitative method includes regression analysis and pairwise correlation analysis which was used in explaining information obtained from audited annual report of quoted manufacturing company.

In other to examine if separation of ownership and control affects the performance of listed manufacturing company in Nigeria in objective one of the study, the following model-equation was designed;

$\mathrm{SEPoc}=\alpha_{0}+\beta_{1} \mathrm{SO}_{\mathrm{it}}+\beta_{2} \mathrm{SC}_{\mathrm{it}}+\beta_{3} \mathrm{ROI}_{\mathrm{it}}+\beta_{4} \mathrm{ROE}_{\mathrm{it}}+\varepsilon_{\mathrm{it} \ldots . . . \mathrm{Eq}(1)}$

To determine the significance effect of laws/regulators on the performance of listed manufacturing company in Nigeria in objective two we adopt the following model

$\mathrm{LR}=\alpha_{0}+\beta_{1} \mathrm{SR}_{\mathrm{it}}+\beta_{2} \mathrm{AAS}_{\mathrm{it}}+\beta_{3}$ ROIit $+\beta_{4} \mathrm{ROEt}_{\mathrm{it}}+\varepsilon_{\mathrm{it} \ldots \ldots} \ldots$ Eq (2) 


\section{Result and discussion}

Table 1

Results of the Regression Analysis Showing the Relationship between Separation of Ownership and Control on the Performance of Listed Manufacturing Company

\begin{tabular}{|l|l|l|l|l|l|ll|}
\hline $\begin{array}{l}\text { Dependent } \\
\text { variables }\end{array}$ & $\begin{array}{l}\text { Independent } \\
\text { variables }\end{array}$ & Coefficient & $\begin{array}{l}\text { Standard } \\
\text { Error }\end{array}$ & $\mathbf{T}$ & $\mathbf{p}>|\mathbf{t}|$ & {$[\mathbf{9 5 \%}$ conf. interval] } \\
\hline SEPoc & SO & 0.0002971 & 0.0002509 & 1.18 & 0.290 & -0.000348 & 0.0009421 \\
\hline & SC & -0.0055759 & 0.0007714 & -7.23 & 0.001 & -0.0075587 & -0.0035931 \\
\hline & ROI & -3852.089 & 651.6826 & -5.91 & 0.002 & -5527.292 & -2176.885 \\
\hline & ROE & -4.844139 & 0.4569881 & -10.6 & 0.000 & -6.018864 & -3.66941 \\
\hline & Constant & 137589.1 & 14354.03 & 9.59 & 0.000 & 100690.9 & 174487.4 \\
\hline
\end{tabular}

Source: Researcher's Computation, 2020.

Table 2

Result of pairwise correlation between Separation of Ownership and Control on the Performance of Listed Manufacturing Company

\begin{tabular}{|l|l|l|l|l|l|}
\hline & SEPoc & SO & SC & ROI & ROE \\
\hline SEPoc & 1.0000 & & & & \\
\hline SO & -0.5608 & 1.0000 & & & \\
\hline SC & -0.3035 & 0.4147 & 1.0000 & & \\
\hline ROI & 0.1970 & -0.4701 & 0.0129 & 1.0000 & \\
\hline ROE & $-0.6714^{*}$ & 0.4742 & -0.3219 & $-0.6368^{*}$ & 1.0000 \\
\hline
\end{tabular}

Source: Researcher's Computation, 2020.

A multiple regression analysis whose equation is presented in Table 1 found that the coefficient of determination (R-square) is 0.9712 . This shows that the predictive power of the independent variable (separation of ownership and control variables) as used to explain variation in the dependent variable (performance of an organization) is about $97 \%$ with a high adjusted R-square of $(0.9481)$. The combined $\mathrm{P}$ value of 0.0005 and FValue of 42.14 shows there is a significant relationship and effect between the variables examined. The regression equation is as shown below.
SEPoc
137589.1
$0.000297 \mathrm{SO}$
$0.00558 \mathrm{SC}$
3852.089ROI

4.844ROE.

The result shows that a unit increase in SEPoc will show a marginal positive contribution of 0.00029 to variation of SO, SC had a marginal negative contribution of about 0.0055 to the variation in SO. ROI indicated a negative contribution of 3852.089 to changes in SEPoc, while ROE showed a negative contribution of about 3.844 to changes in SEPoc. Furthermore, three of the four variables are significant in predicting the changes in SEPoc. These are SC with a value of 7.23 and $p$ - value of 0.001 , ROI with a t-value of 0.002 and p-value of 0.000 and ROE with a $t$ and $p$ values of 10.60 and 0.000 respectively.

A pairwise correlation test between the variables indicates similar result given correlation between SEPoc and other explanatory variables. The coefficient of correlation (R) between SO and SEPoc is $(-0.5608)$, an indication of moderate negative relationship. SC has an insignificant negative correlation of (0.3035) with SEPoc and the variable OS has a weak but positive correlation coefficient of $(0.1970)$ with SEPoc. ROE shows a negative but significant correlation coefficient of (0.6714) with SEPoc. as shown in table 2.

Table 3

Result of Regression Analysis showing the Relationship between Laws/Regulators and the Performance of Listed Manufacturing Company in Nigeria

\begin{tabular}{|l|l|l|l|l|l|ll|}
\hline $\begin{array}{l}\text { Dependent } \\
\text { variables }\end{array}$ & $\begin{array}{l}\text { Independent } \\
\text { variables }\end{array}$ & Coefficient & $\begin{array}{l}\text { Standard } \\
\text { Error }\end{array}$ & $\mathbf{T}$ & $\mathbf{p}>|\mathbf{t}|$ & {$[\mathbf{9 5 \%}$ conf. interval] } \\
\hline LR & SR & 1.319006 & 6.34784 & 0.21 & 0.844 & -17.63665 & 14.99864 \\
\hline & AAS & 97.06288 & 35.45239 & 2.74 & 0.041 & -188.1961 & -5.929617 \\
\hline & ROI & -141881.8 & 40395.71 & -3.51 & 0.017 & -245722.3 & -38041.3 \\
\hline & ROE & -17.49959 & 6.487834 & -2.70 & 0.043 & -34.1771 & -.8220864 \\
\hline & Constant & 4090446 & 974707.2 & 4.20 & 0.009 & 1584881 & 6596011 \\
\hline
\end{tabular}

Source: Researcher's computation, 2020. 
Table 4

Result of a pairwise correlation between Laws/Regulators and the Performance of Listed Manufacturing Company in Nigeria

\begin{tabular}{|l|l|l|l|l|l|}
\hline & LR & SR & AAS & ROI & ROE \\
\hline LR & 1.0000 & & & & \\
\hline SR & 0.3177 & 1.0000 & & & \\
\hline AAS & -0.3725 & 0.1195 & 1.0000 & & \\
\hline ROI & -0.0303 & 0.1970 & -0.6235 & 1.0000 & \\
\hline ROE & -0.5105 & -0.6839 & 0.3073 & -0.6171 & 1.0000 \\
\hline
\end{tabular}

Source: Researcher's computation, 2020.

Findings based on the result obtained in Table 3 , indicate that R-square $=0.8031$, which implies that approximately $80 \%$ of the variation in the dependent variable (LR) is caused by the explanatory variables included in the model and remained robust at 0.6456 after adjusting for degree of freedom. Moreover, the explanatory variables are jointly significant at $5 \%$ level as captured by F-statics $(51.10)$ with a corresponding P-value of the 0.0017 . The general model of the equation is presented in equation 4.3 below:
$\mathrm{NP}=\quad 4090446$
1.319SR
97.062AAS
- $\quad$ 141881.8IROI
17.49959ROE.................................................... (4.2)

The result implies that three of the four explanatory variables are significant in explaining variation in LR. These are AAS, ROI and ROE with a $t$ and $p$ values of $(2.74$ and 0.041$),(-3.51$ and 0.017$)$ and $(-2.70$ and 0.043$)$ respectively. Moreso, two of the variables (SR and AAS) shows positive effect on LR, while the other two variables (ROI and ROE) exhibit negative effect. A unit increase in SR and AAS will lead to (1.319) and (97.062) increase in LR respectively. Furthermore, ROI and ROE were found to have negative coefficient of -141881.8 and 17.49959 respectively. However the combined statistics shows that there is a significant relationship between effect of laws/regulators and the performance of listed manufacturing company in Nigeria given $F(4,5)=51.10$ and P-value of 0.0017 .

Moreover, the pairwise correlation test between the study variables in table 4 further affirms the relationship between laws/regulators on the performance of listed manufacturing company in Nigeria. The correlation coefficient (R) between SR and LR was found to be 0.3177 , an indication of low positive relationship between the two variables. AAS shows correlation coefficient of -0.3725 with LR. ROI shows negative and insignificant coefficient of -0.0303 , while ROE and AAS exhibit a negative but moderate correlation with a coefficient of 0.5105 as shown in table 4

\section{Discussion of Findings}

The first objective seeks to examine if separation of ownership and control affects the performance of listed manufacturing company within a period of ten years (2010-2019). Findings from the study revealed that there is a significant relationship and effect between separation of ownership and control on the performance of listed manufacturing company. Components such as Separation of ownership and control (SEPoc), Share of ownership (SO), Return on Investment (ROI), Return on Equity (ROE) were found to have a significant effect on the performance of listed manufacturing company (proxied by Separation of ownership and control (SEPoc) given a $\mathrm{P}$-value of 0.0005 , R-Squared of 0.9712 , adjusted $\mathrm{R}^{2}$ of 0.9481 and F-value of 42.14 . Furthermore the study evaluates the Relationship between laws/regulators on the performance of listed manufacturing company in Nigeria. Results from the analysis revealed that the combined effect of laws/regulators on the performance of listed manufacturing company in Nigeria (LR) is significant given a P-Value of 0.0017 and F-Value of 51.10, $\mathrm{R}^{2}$ of 0.8031 and adjusted $\mathrm{R}^{2}$ of 0.6456

\section{Conclusion and Recommendations}

This study examines the impact of impact of corporate governance and external mechanism on organizational performance in Nigeria within a period of ten (10) years (2010-2019). The empirical results of this study revealed that external mechanism of corporate governance has impact on the performance of manufacturing firms in Nigeria. In relation to the objective of the study, the study concludes that there is a significant relationship and effect between separation of ownership and control on the performance of listed manufacturing company. Components such as Share of Ownership (SO), Separation of Control (SC), Return on Investment (ROI), and Return on Equity were found to have a significant effect on the performance of manufacturing firms in Nigeria (proxied by Separation of Ownership and Control (SEPoc). Also, there is significant positive relationship between laws/regulators on the performance of listed manufacturing company in Nigeria (Law/Regulations). Based on the findings and conclusion, the study therefore recommends that regulatory bodies should ensure that the manufacturing companies comply with the statutory rules and regulations of corporate governance act. A fair and balanced board composition should be adopted by manufacturing companies to ensure proper direction of strategy and long-term maximization of owners' value. The linkage between external mechanism and firm performance 
implied that for return on investment (ROI) to increase, there is need to link their operations and output to the overall board operations.

\section{References}

Adebuyo, M. Ibrahim A. O. Yusuf, B. and Omah I. (2014). Good Corporate Governance and Organizational Performance: An Empirical Analysis. International Journal of Humanities and Social Sciences 4(7) 170-178.

Adenikinju, O. and F. Ayorinde. (2017). “Ownership structure, corporate governance and corporate performance: The case of Nigerian quoted companies”. Final Report presented at the AERC biannual research workshop, Nairobi.

Ammar, A. G. Asif, S. and Ammar Abid (2013). Corporate Governance and Performer: An Empirical Evidence from the Textile Sector of Pakistan, African Journal of Business Management 7(22) 2112-2118.

Babatunde, A. and Olaniran, O. (2009). The Effect of Internal and External Mechanism on Governance and Performance of Corporate Firms in Nigeria. Journal of Corporate Ownership \& Control 7(2) 330-344.

Bessong, P. K. and Tapang A. T. (2012). Social responsibility accounting cost and its influence on the profitability of Nigerian Banks. International Journal of Financial Research, 3 (4), 33-45

Cadbury Report, (2012) Report of the Committee on the Financial Aspect of Corporate Governance. Gee Publishing, London.

Core, J.E., R.W. Holthausen, and D.F. Larcker, (2009). Corporate Governance, Chief Executive Officer Compensation, and Firm Performance, Journal of Financial Economics 51(3), pp. 371- 406.

Freeman, R. E. (2004). "Strategic Management: A Stakeholder Approach.” London: Pitman.

Frydman, Roman, Cheryl W. Gray, Marek Hessel, and Andrzej Rapaczynski (1999), "When Does Privatization Work? The Impact of Private Ownership on Corporate Performance in the Transition Economies." Quarterly Journal of Economics, Vol. 114/4, 1153-1192.

Gompers, P, J. Ishii and A. Metrick, (2013). "Corporate Governance And Equity Prices," The Quarterly Journal of Economics, MIT Press, vol. 118(1), pages 107-155, February

Gugler, K. (Eds) (2012) Corporate Governance and Economic Performance. Oxford University Press.

Hermalin, B.E. and M.S. Weisbach. (2014). "The effects of board composition and direct incentives on firm performance". Financial Management, Winter: 101-12.

Hermalin, B.E. and M.S. Weisbach. (2014). "The effects of board composition and direct incentives on firm performance". Financial Management, Winter: 101-12.

Jensen K and Michael C. (2011). "Value maximization, stakeholder theory, and the corporate objective function". Working paper No. 01, Harvard Business School.

Jensen, M and Meckling W. (1976). Theory of a Firm: Managerial Behaviour, Agency Costs and Ownership Structure. Journal of Economics.

Magbagbeola, N.O (2015) Governance Structure Managerial Characteristics and firms performance in the Nigeria bank industries. Final report submitted to African Economic Research Consortium, Johannesburg, South Africa

Metrick, A. and J. Ishii. (2012). "Firm-level corporate governance". Paper presented at Global Corporate Governance Forum Research Network Meeting, Washington, D.C. April.

Miyajima Hideaki, Kenji Haramura, and Yoshinari Enami. (2015). The structure of shareholding in post-war Japan: The formation and dissolution of stable shareholdings. Financial Review, no. 68:203-36.

Monks, R. and Minow N. (1995) Corporate Governance 2nd ed. Blackwell Publisher, Oxford.

Nigerian Stock Exchange. (2019). Fact Book. Nigerian Stock Exchange, Lagos, Nigeria.

OECD (2014). Organization for Economic Co-operation and Development. "The OECD Principles of Corporate Governance",

Ogbechie, C., and Koutopoulos, D. N. (2010). Corporate Governance and Board Practices in the Nigerian Banking Industry

Shleifer, A and Vishny, R. W., (2016) A Survey of Corporate Governance. NBER Working Paper No. W5554. April.

Wolfensohn, J. (2009) Corporate Governance is about Promoting Corporate Fairness, Transparency and Accountability; Financial Times, June, $21^{\text {st }}$

Yermack, D. (1996). Higher Market Valuation of Companies with a Small Board of Directors, Journal of Financial Economies, 40185-221. 